\title{
III. Cultura digital
}

\section{Enseñar Historia (reciente) en contextos de cultura digital. Una experiencia de formación e intercambio entre Argentina y España por Victor A. Salto y Joan Llusà Serra \\ Universidad Nacional del Comahue/ Universidad Autónoma de Barcelona, España. victorsalto26@gmail.com, jllusa@xtec.cat \\ Recibido: 06|04|2015 - Aceptado: 27|04|2015}

\section{Resumen}

El presente artículo presenta una experiencia de intercambio y colaboración sobre la enseñanza de la historia reciente entre dos realidades educativas muy distantes, pero que comparten una misma finalidad de innovación educativa y de formación de los valores democráticos en el marco de los actuales contextos de cultura digital. La misma fue llevada a cabo con estudiantes de nivel secundario de $3^{\circ}$ año del Centro Provincial de Enseñanza Media N ${ }^{\circ} 41$ (Neuquén Capital, Argentina) y de $4^{\circ}$ año del colegio Fedac Sant Vicenç (Barcelona, España).

En la base de nuestra experiencia ubicamos la necesidad de enseñar historia a partir de problemas sociales relevantes, el uso de las nuevas tecnologías y el propósito de dar un mayor protagonismo a nuestros estudiantes en el proceso de aprendizaje. Nos planteamos tanto la motivación de nuestros estudiantes como de buscar otras formas para enseñar una historia realmente comprensiva que los capacitase para llevar los aprendizajes desarrollados a sus propias vidas.

Palabras clave

historia reciente, cultura digital, nuevas tecnologías, problemas socialmente relevantes, enseñanza de la Historia 


\section{Teaching recent history in context of digital culture. An experience of formation and educational exchange between Spain and Argentina}

\section{Abstract}

This article presents an experience exchange and collaboration on the teaching of recent history between two very distant educational realities, but sharing the same goal of educational innovation and training of democratic values in the context of the current contexts of culture digital. It was carried out with high school students in 3rd. year of the Provincial Centre for Media Education 41 (Neuquén, Argentina) and four years of college Fedac Sant Vicenç (Barcelona, Spain).

On the basis of our experience is the need to teach history from relevant social problems, the use of new technologies and the purpose of giving greater prominence to our students in the learning process. We considered both the motivation of our students and find other ways to teach a truly comprehensive history that capacitase developed to bring learning to their own lives.

Keywords

recent history, digital culture, new technologies, socially relevant problems, teaching of the history

$\cos$

\section{La enseñanza de la Historia en contextos de cultura digital}

"Los conocimientos disciplinares son necesarios pero no suficientes para que los alumnos puedan vivir y actuar de forma responsable en una sociedad democrática. Además de información, es necesario aprender unos valores a fin de poder actuar en el futuro de forma coherente y participativa.» (Oller, y Pagès, 1999:3)

Indudablemente, en un mundo global, complejo, incierto y de alta velocidad como el nuestro prevalece una influencia considerable de la cultura digital. La cual obedece a un avance, en cierta forma desmesurado, de las nuevas tecnologías de la información y comunicación desarrolladas desde las últimas décadas del siglo XX.

Pero, como afirma Santisteban (2013), en sociedades saturadas de información y de espectáculo, el acceso al conocimiento no siempre está garantizado ni corre como posibilidad con la misma vehemencia con la que circula la información misma. Por ello, estamos convencidos que desde la enseñanza de la historia se pueden promover experiencias que permitan la construcción de conocimientos a partir de los aportes de las nuevas tecnologías de la comunicación y de la información prevaleciente. Conocimientos que son necesarios no sólo para ayudar a relacionar pasados-presentes-futuros sino también para formar en la consciencia temporal que permita pensar y discernir sobre otras construcciones didácticas y escolares posibles en las sociedades actuales. 